\title{
Chemostratigraphic constraints on the time of deposition of carbonate rocks in the Karasjok Greenstone Belt, northern Norway
}

\author{
Victor A. Melezhik' ${ }^{1}$ Arne Solli' ${ }^{1}$ Anthony E. Fallick² \& Børre Davidsen' \\ ${ }^{1}$ Geological Survey of Norway, Postbox 6315 Sluppen, 7491, Trondheim, Norway. \\ ${ }^{2}$ Scottish Universities Environmental Research Centre, Rankine Avenue, G75 OQF East Kilbride, Scotland. \\ E-mail corresponding author (Victor A. Melezhik): victor.melezhik@ngu.no
}

\begin{abstract}
The time of deposition of the rocks of the Karasjok Greenstone Belt, the most continuous and longest, linear Precambrian terrane in northern Norway, remains poorly dated. The belt is composed of several volcanic and sedimentary formations including a continuous unit of calcite and dolomite marbles. Most rocks have been strongly deformed and altered under amphibolite-facies metamorphism. Carbon isotope chemostratigraphy has been applied to provide an apparent depositional age of carbonate units and associated sedimentary and volcanic rocks. Thirty-eight samples representing marbles in four different locations in the northern part of the belt show high $\delta^{13} \mathrm{C}_{\text {carb }}$ values, hence recording the Palaeoproterozoic Lomagundi-Jatuli isotopic event. The least-altered $\delta^{13} \mathrm{C}_{\text {carb }}$ values suggest the presence of two isotopically different assemblages $(+8$ to $+9 \%$ and +12 to $+14 \%$ ) whose apparent time of deposition can be constrained between 2220 and $2140 \mathrm{Ma}$, and between 2220 and $2110 \mathrm{Ma}$, respectively.
\end{abstract}

Keywords: Palaeoproterozoic, Norway, marble, carbon isotopes

Received 5. August 2015 / Accepted 7. November 2015 / Published online 4. December 2015

\section{Introduction}

The Karasjok Greenstone Belt (KGB) represents a 160 $\mathrm{km}$-long and $40 \mathrm{~km}$-wide linear Precambrian structure situated in the northwestern part of the Precambrian Fennoscandian Shield in Finnmark, northern Norway (Fig. 1). In the north, the KGB is overlain by autochthonous Ediacaran (Vendian) to Cambrian sedimentary successions of the Dividal Group which are overthrust by the Caledonian nappes. The KGB extends for another $150 \mathrm{~km}$ to the south into northern Finland where it is named the Kittilä Greenstone Belt. The KGB has a potential for discovery of economic ore deposits (e.g., Often, 1985). However, the lack of robust radiometric data constraining the time of deposition of its sedimentary and volcanic complexes (e.g., Krill et al., 1985; Marker et al., 2000) hampers chronostratigraphic correlations of the sedimentary and volcanic successions with those occurring in neighbouring Finland and elsewhere in the Fennoscandian Shield. In addition, this imposes problems on fully understanding the evolution of the greenstone belt and hampers the choice of prospecting and exploration strategy. Consequently, the goal of this study is to provide constraints on the age of some of the sedimentary formations by employing the $\mathrm{C}$-isotope chemostratigraphic approach. 


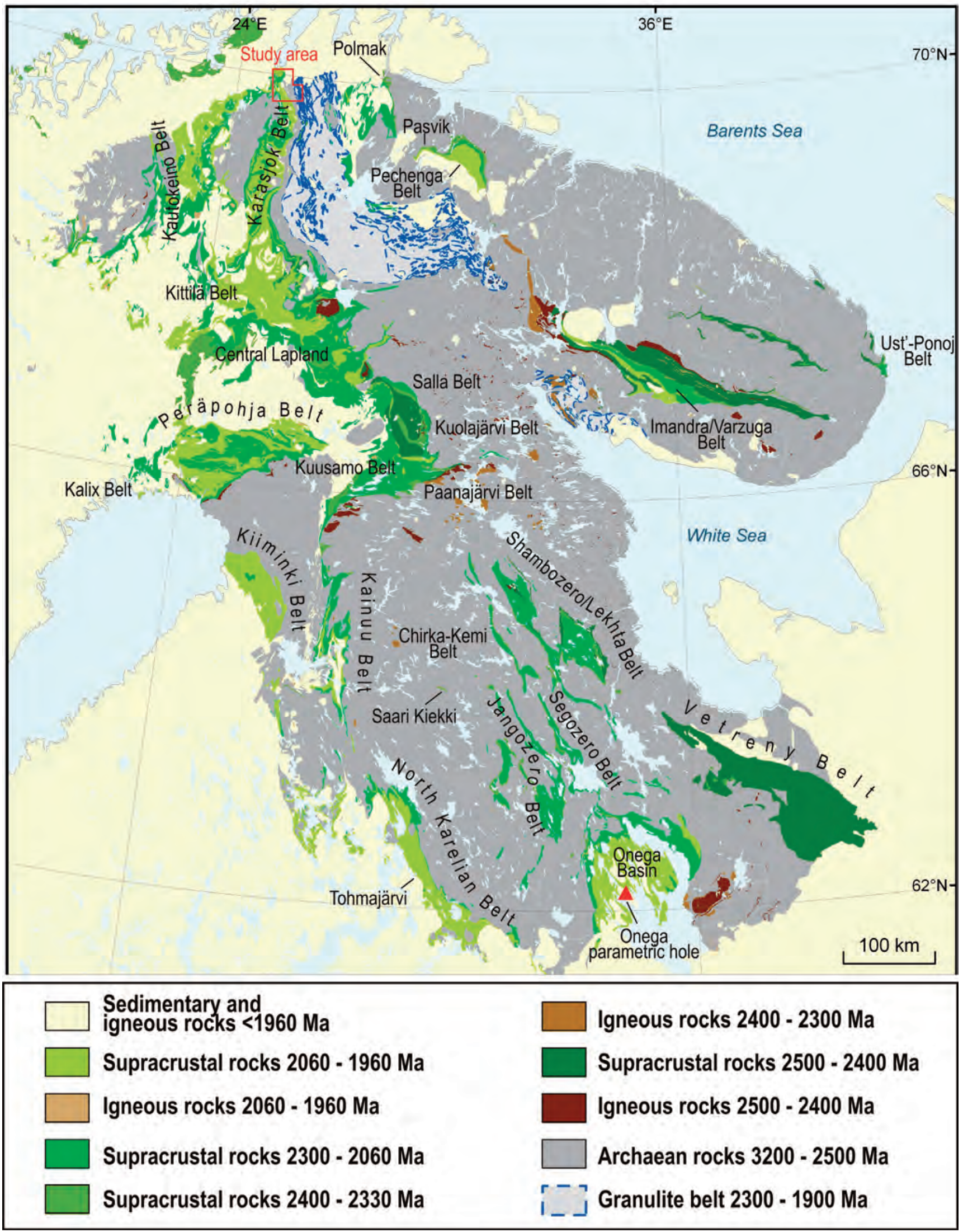

Figure 1. Geological map of the eastern part of the Fennoscandian Shield emphasising the Early Palaeoproterozoic rocks and showing the location of the study area (in the northwest corner). The map is based on Koistinen et al. (2001). 


\section{Tectonic setting, depositional environments and main litho-/ tectonostratigraphic units}

The volcanosedimentary succession of the KGB overlies the Jergul Gneiss Complex in the west and dips away beneath the overthrusted Tanaelv Migmatite Complex in the east (Figs. 2, 3). The KGB rocks underwent greenschist- to amphibolite-grade metamorphic alteration and were highly deformed during the Late Palaeoproterozoic Svecofennian orogeny. In the text that follows we purposely omit the prefix 'meta'. A robust stratigraphy for the volcanosedimentary succession is yet to be established. Two parallel, poorly correlated lithostratigraphic subdivisions have been proposed (Fig. 4) and their detailed descriptions summarised and documented by Siedlecka et al. (1985), Siedlecka (1985), Often (1985) and Davidsen (1994).
Litho-/tectonostratigraphy and depositional environment of the southern part of the KGB

Siedlecka et al. (1985), Siedlecka (1985) and Often (1985) subdivided the volcanosedimentary succession of the KGB into five tectonostratigraphic units (Fig. 4C). The three upper units comprise the Iddjajav'ri Group, the type section for which is located in the southern part of the KGB where there is generally a low degree of outcrop and only sparse indicators of stratigraphic polarity. Hence, the identification of possible stratigraphic repetitions caused by isoclinal folding and/or thrusting is difficult to detect (cf., Siedlecka, 1985). A brief summary of the tectonostratigraphy of this southern area is given below.

The Vuomegielas Formation

The Vuomegielas Formation represents the lowermost structural unit whose lower boundary remains unknown. Lithologically homogeneous, it consists of

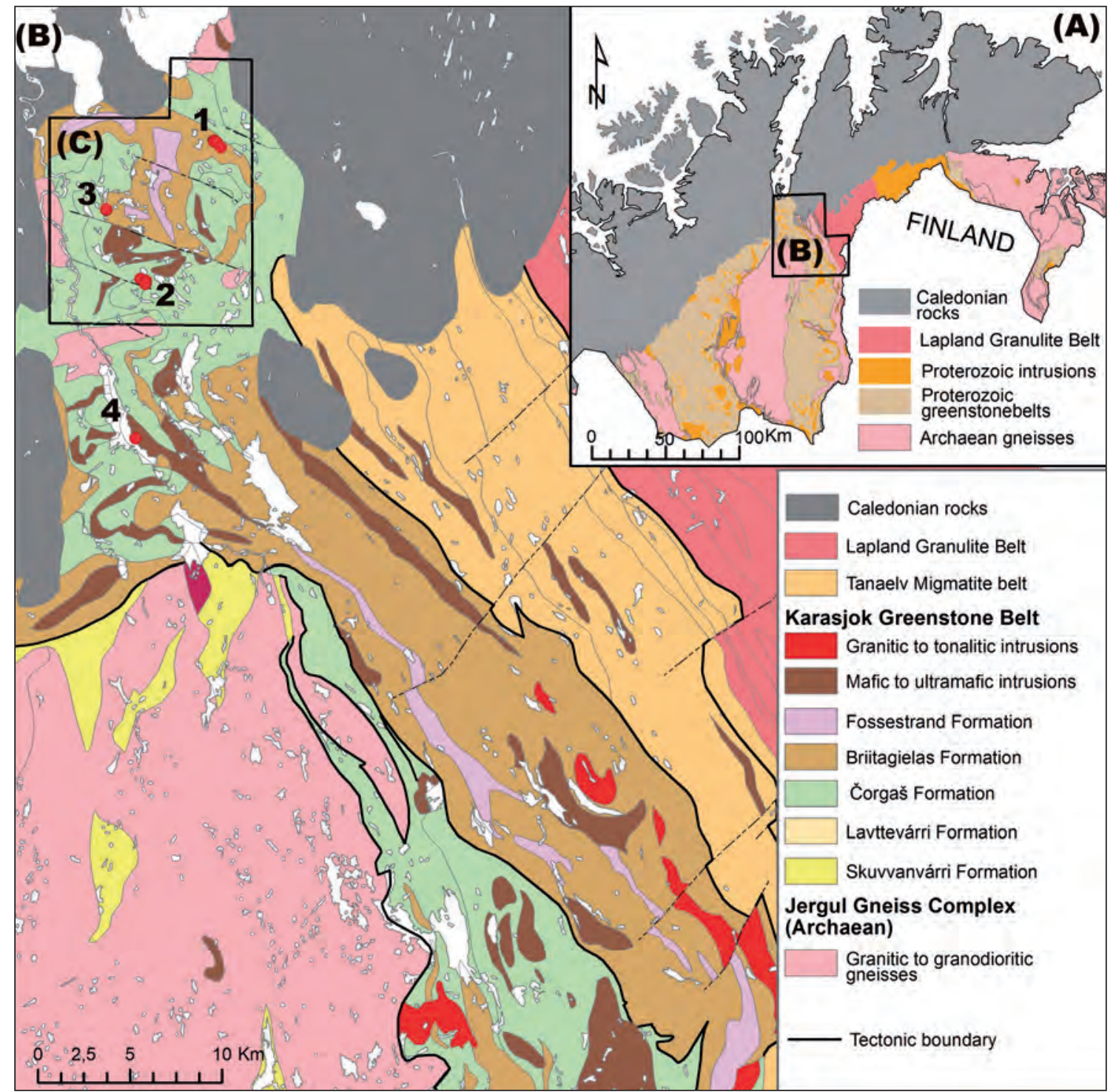

Figure 2. (A) Inset map showing location of the study area in Finnmark, northern Norway, and (B) schematic geological map of the northern and middle parts of the KGB with locations of the studied/sampled sections (denoted from 1 to 4). The geological map is based on Siedlecka \& Roberts (1996). Detailed geological map of (C) area is shown in Fig. 3. 


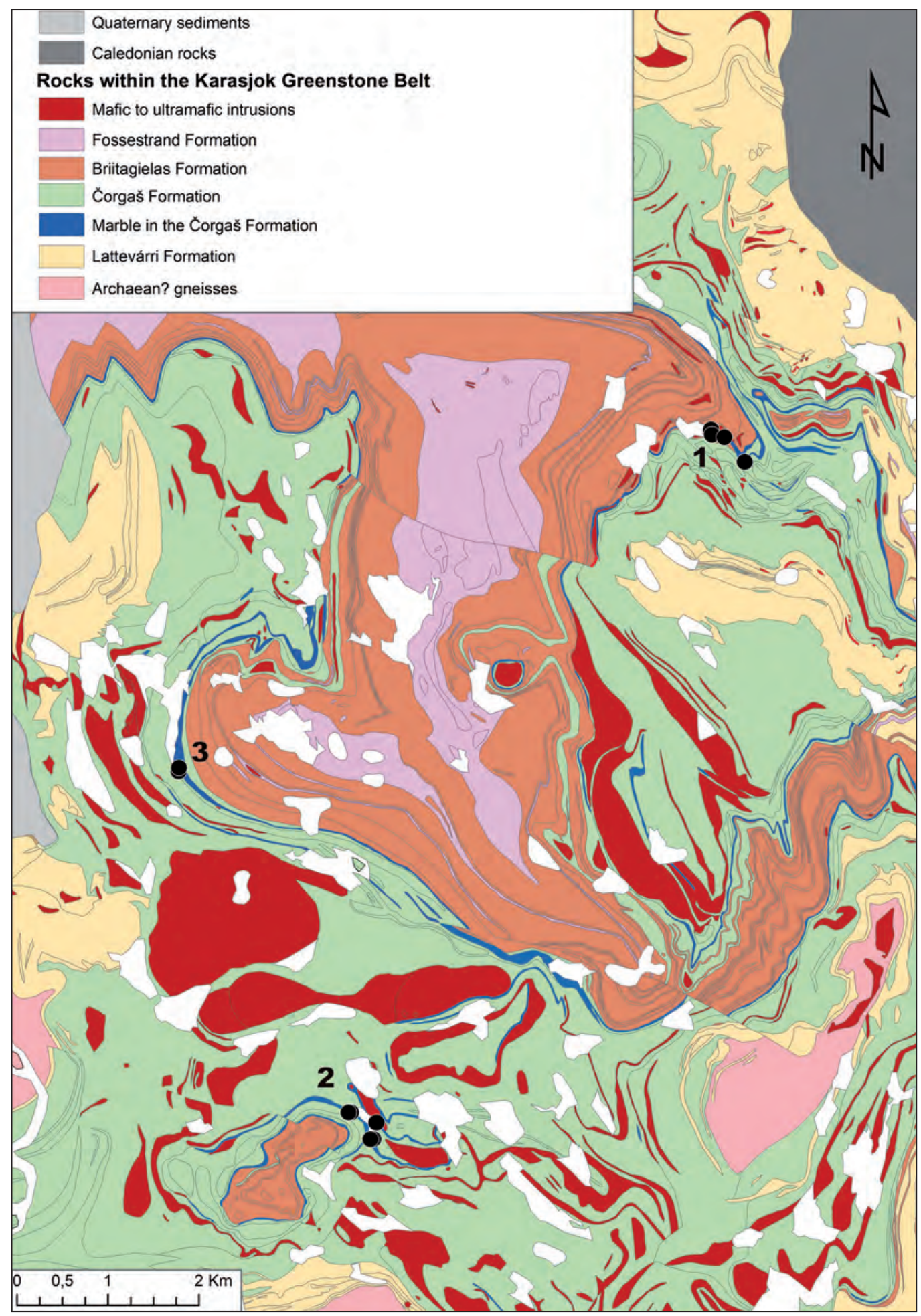

Figure 3. Detailed geological map of the northernmost part of the KGB with locations of the sampled profiles (denoted from 1 to 3). The map is based on Davidsen (1994), Siedlecka et al. (2011) and Roberts \& Davidsen (2011). The geology of the northern part of this map has been described in detail in Davidsen (1994).

a foliated, finely crystalline amphibolite showing in places high $\mathrm{Mg}$ and low Ti contents, hence resembling komatiites (Siedlecka, 1985; Siedlecka et al., 1985). The amphibolites dip beneath the overlying terrigeneous Skuvvanvárri Formation; however, their mutual contact has not been observed. Based on stratigraphic alternation between finely crystalline amphibolite, conglomerate, hornblende schist and quartzite within a 250-300 $\mathrm{m}$-thick transitional zone between these two formations, Siedlecka (1985) suggested a likely primary stratigraphic relationship. 


\section{The Skuvvanvárri Formation}

The Skuvvanvárri Formation represents a dominantly sedimentary succession resting either on the Vuomegielas amphibolites or on the palaeoweathered, in places intensely dolomitised, gneisses of the Jergul Gneiss Complex (a detailed description is published in Siedlecka, 1985). The maximum observed formational thickness is close to $950 \mathrm{~m}$. The upper contact represents a major thrust which, in places, has totally obliterated the formation (Siedlecka, 1985).

The formation consists of pale-grey, matrix-supported conglomerate interbedded with green, fuchsite-bearing, and pink sandstones and mudstones (Siedlecka, 1985). The conglomerates are immature and polymict, lack any internal water-flow features and contain beds of mudstones with scattered pebbles. The sandstones are fine grained, well sorted and in contrast to the conglomerates show a high degree of textural maturity. The sandstones are quartzitic or feldspathic, the latter consisting mainly of albite of unknown origin (Siedlecka, 1985; Often, 1985). Both varieties exhibit large-scale, tabular, herringbone or tangential cross-bedding.

Lithofacies interpretation. Siedlecka (1985) reported a frequent variation in lithofacies distribution in the Skuvvanvárri Formation and described the conglomerates as debris-flow and sheet-flood deposits accumulated on alluvial fans. The sandstone lithofacies was interpreted as either fluvial channel deposits or water- or wind-transported coastal sediments.

\section{The Gollebáiki Formation}

The Gollebáiki Formation is the lowermost unit of the Idjajávri Group, and has a thrust contact with the underlying Skuvvanvárri rocks. Due to abundant recumbent folding the control on total thickness is poor. The best profiles indicate a total thickness of 1000 $1500 \mathrm{~m}$ (Often, 1985). The formation is composed of both volcanic and sedimentary units. The type-section described from the southern part of the belt starts with foliated amphibolites and chlorite-amphibole rocks containing several intervals of Mn-rich, banded iron formations, sulphide-bearing chert, massive sulphide, and subordinate clastic sedimentary and carbonate rocks. The middle part of the formation is dominated by mica schists and sulphide-bearing, poorly banded gneisses of dioritic to quartz-dioritic composition. The gneisses locally contain chalcopyrite and $\mathrm{Cu}-\mathrm{Au}$ mineralisations (Bugge, 1978). The upper part of the formation consists of albite-rich (up to $70 \%$; Elvebakk et al., 1985) feldspathic sandstones with minor haematitebearing shales and mafic volcanic rocks.

Lithofacies interpretation. The formation exhibits a marked facies change between mafic lavas and greywackes. Primary textures are rarely preserved but a few exceptions have been recorded. In places, albite sandstones display well-preserved flaser bedding and herring- bone cross-bedding. Shrinkage cracks are well preserved. All sedimentological features suggest a near-shore to tidal marine environment (Elvebakk et al., 1985). Amygdales in mafic volcanic rocks and volcaniclastic textures in ultramafic volcanites provide additional indications of shallow-water to subaerial conditions (Often, 1985). The nature of the dioritic to quartz-dioritic gneisses remains unknown.

Origin of the Na-rich sandstones. The origin of the high $\mathrm{Na}_{2} \mathrm{O}$ content (6.4-7.9 wt.\%) documented in the albite sandstones (Elvebakk et al., 1985) is puzzling. These sandstones are compositionally similar to rocks locally termed albite felsites (fine-grained, thinly laminated, albite-rich rocks) occurring in the Kautokeino Greenstone Belt, and to Na-rich Palaeoproterozoic rocks known from other places across northern Fennoscandia (Tuisku, 1985; Olerud, 1988; Ettner et al., 1994; Frietsch et al., 1997; Eilu, 1994; Mänttäri, 1995; Vanhanen, 2001; Kyläkoski et al., 2012; Melezhik et al., 2012, 2013a). A volcaniclastic origin combined with diagenetic Na-metasomatism (e.g., Surdam \& Boles, 1979) has been suggested as a possible explanation for the Gollebáiki Na-rich sandstones (Elvebakk et al., 1985; Often, 1985). Melezhik et al. (2015) have suggested that an abundant former presence of Palaeoproterozoic halite, subsequently dissolved and mobilised during the course of the post-depositional history, may represent the most probable source of sodium in metasomatically altered rocks in northern Fennoscandia.

\section{The Báhkilvárri Formation}

The lower boundary of the formation is transitional into the sedimentary rocks of the Gollebáiki Formation, but is commonly tectonically overprinted. The formation represents a monotonous succession of foliated, garnetbearing amphibolites, originally tholeiitic basaltic lavas, tuffs and tuffites with an unknown number of dykes and sills (Henriksen, 1983; Often, 1985). Rare pillow structures have been observed in the amphibolites.

Chlorite-amphibole rocks, primary komatiites (Henriksen, 1983), occur in the middle and upper parts of the formation. Primary depositional features are common, showing a dominance of pyroclastic material with grain sizes ranging from fine tuff to breccias. Blocks of amygdaloidal lavas are common. Well-preserved pillows have been described in some localities (Often, 1985). Massive flows are uncommon. Henriksen (1983) described microscopic textures that might represent microspinifex.

Terrigenous sediments, mainly greywackes, are a minor constituent of the formation. Chemical precipitates, such as manganese-bearing banded iron formations, are associated with the komatiites. Sulphide-rich intervals represent either lateral extensions of the iron formations or separate layers within the mafic volcanites.

Lithofacies interpretation. Wennervirta (1969) recognised the effusive character of the komatiitic rocks and used 


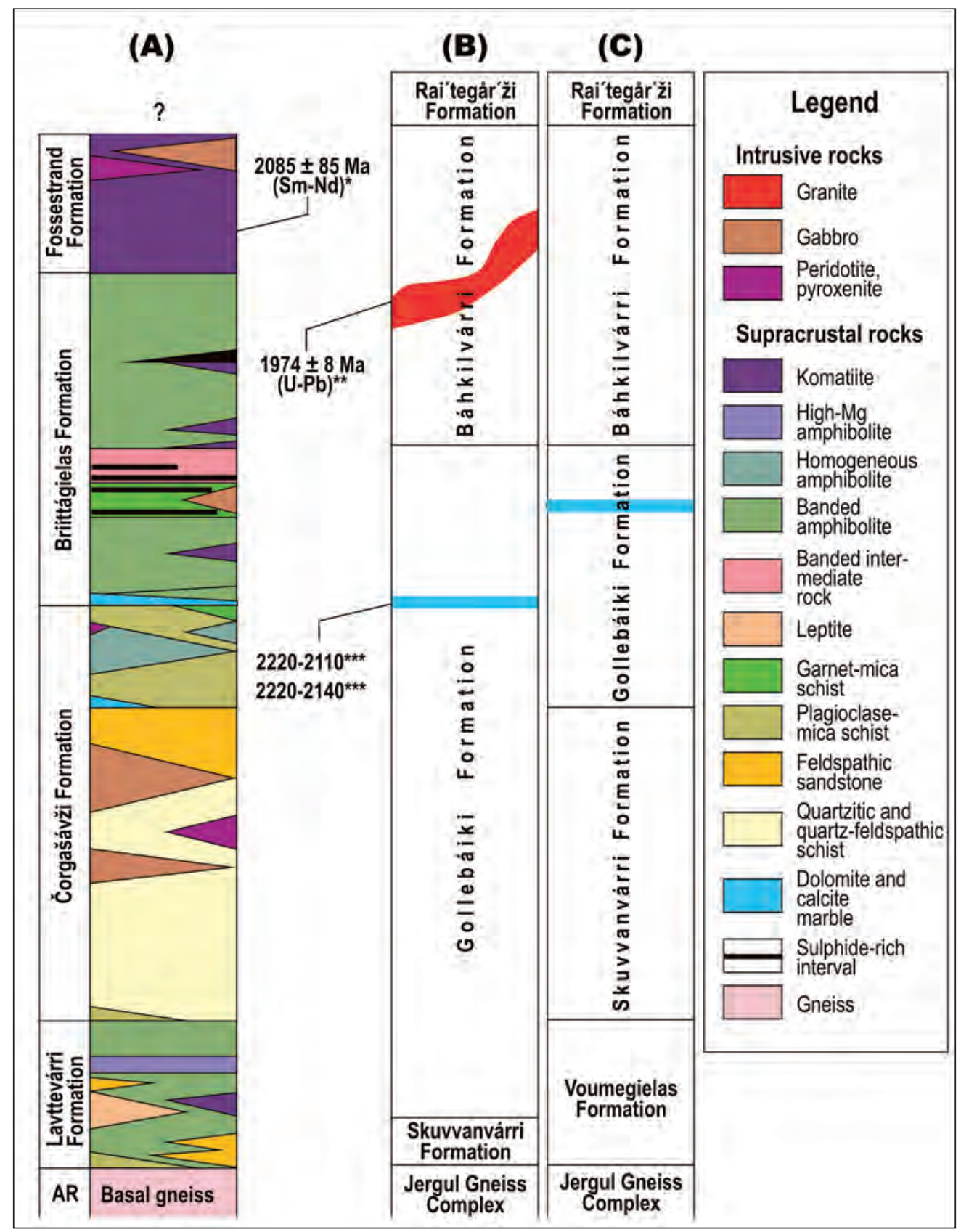

Figure 4. (A) Lithostratigraphic column of the $K G B$, and $(B, C)$ its alternative correlation with litho-/tectonostratigraphic subdivisions previously advanced by Often (1985) (modified from Davidsen, 1994). The radiometric and chemostratigraphic dates are from: $\left(^{*}\right)-$ Krill et al. (1985), (**) - Marker et al. (2000), (**) - this study.

the term agglomerate in a broad sense, combining all coarse-grained volcanic breccias and conglomerates. The presence of pillows provides evidence of a subaqueous environment, whereas vesicles in the same pillows and the abundance of pyroclastic material are indicative of a relatively shallow-water setting (Often, 1985).

The Rai'tegår'ži Formation

The Rai'tegår'ži Formation conformably overlies the Báhkilvárri Formation and consists of mica schists and amphibolites. The latter are indistinguishable from those of the underlying Báhkilvárri Formation, and due to the limited exposure these two formations have not been mapped separately in most parts of the KGB. The Rai’tegår ži mica schists and amphibolites have been strongly deformed and partly migmatised towards the Tanaelv Migmatite Complex (Fig. 2). No primary depositional features were observed. An apparent thickness of the formation is reported to be several kilometres. The upper boundary with the Tanaelv Migmatite Complex is tectonic. 


\section{Litho-/tectonostratigraphy and depositional environment of the northern part of the KGB}

Braathen \& Davidsen (2000) described the volcanosedimentary succession of the KGB using a type section located in the northern part of the KGB. They stated that this section "represents the best known and probably one of the most complete sections through the KGB". They subdivided the volcanosedimentary succession into four formations (Fig. 4A). A brief summary of their tectonostratigraphy is given below.

\section{The Lavttevárri Formation}

The Lavttevárri Formation is $50-150 \mathrm{~m}$ thick and rests unconformably on Archaean granitic gneisses. Rocks occurring above the basal unconformity are carbonatebearing mica schists (locally fuchsite-bearing) with conglomeratic intervals containing clasts of vein quartz and also granite and granitic gneiss from the basement. These are overlain by schistose tholeiitic amphibolites and sandstones, subordinate komatiites, possible rhyolitic volcanites, mica schists and marbles (Braathen \& Davidsen, 2000).

\section{The Čorgašávži Formation}

The Čorgašávži Formation is $250(?)-700 \mathrm{~m}$ thick and interfingers with the underlying Lavttevárri rocks. Recently, the Čorgašávži Formation has been renamed as the Čorgaš Formation in the 1:50,000 mapsheets Skoganvarri and Lakselv, which were published after Braathen \& Davidsen (2000). The formation is composed mainly of sandstones; however, the upper part of the formation includes tholeiitic, amygdaloidal lava flows intercalated with mica schists. Intervals of conglomerates and marbles are also present. Gabbros and minor pyroxenitic bodies are common (Braathen \& Davidsen, 2000).

\section{The Briittágielas Formation}

The Briittágielas Formation is $300-700 \mathrm{~m}$ thick. The basal part of the formation is marked by the occurrence of a thick marble unit (calcite-dolomite-tremolite rocks). This is followed by kyanite-bearing, garnet-mica schists and possible calc-alkaline dacitic volcanites with intervals of graphite-bearing schist. The rest of the formation is composed of banded amphibolites (tholeiitic basalt) and volcaniclastic and pillowed komatiites occurring in four different units, each up to $70 \mathrm{~m}$ thick (Braathen \& Davidsen, 2000). Several intervals of massive sulphide mineralisation occur throughout the stratigraphy.

\section{The Fossestrand Formation}

The Fossestrand Formation has a minimum thickness of 250-300 m. Two thick, pillowed lava flows occur in the lower part of the formation followed by agglomeratic/ volcaniclastic deposits. The bulk of the formation is composed mainly of komatiitic and coarse-grained mafic volcanic rocks.

\section{Lithofacies interpretation}

Braathen \& Davidsen (2000) inferred that, on the whole, the sedimentary-volcanic succession studied in the northern part of the KGB was deposited under subaqueous conditions, as based on the presence of the pillow lavas and graphite-bearing schists. The preserved depositional contacts against Archaean granitic basement indicate that at least the lowermost formation has been deposited in an intracratonic palaeotectonic setting. The abundance of thick sedimentary units dominated by material from granitoid sources indicates the presence of cratonic source areas in close proximity to the depositional site (Davidsen, 1994).

\section{North-to-south lithostratigraphic correlation}

Braathen \& Davidsen (2000) reported that no significant tectonic breaks have been observed between any of their four formations. Based on this, Braathen \& Davidsen (2000) have suggested that their subdivision is very likely to represent a lithostratigraphy (Fig. 4A). They also offered two alternative scenarios (Fig. 4B, C) for the correlation of their subdivisions with those previously advanced by Siedlecka (1985) and Often (1985). This correlation scheme suggests that the Gollebáiki and Báhkilvárri formations recognised by Often (1985) and Siedlecka (1985) in the southern part of the belt, correspond mainly to the Čorgaš and Briitagielas formations of Braathen \& Davidsen (2000), defined in the northern part of the belt (Fig. 4).

Often (1985) stated that in the northern part of the belt the predominantly psammitic lithology of the Gollebáiki Formation terminates with a marble and mica schist unit that constitutes an excellent marker horizon (Crowder, 1959; Pharaoh, 1981, 1984). Indeed, the recently published 1:50,000 geological map demonstrates that there is a marble unit which is continuous over several kilometres in at least the northern part of the KGB (Fig. 3). In contrast, Braathen \& Davidsen (2000) have reported two carbonate units (Fig. 4A). One occurs in the upper part of the Čorgašávži Formation whereas the second, much thicker unit, forms the base of the Briittágielas Formation. However, the 1:50,000 geological map which adopted Braathen and Davidsen's lithostratigraphy shows that the thickest carbonate unit occurs in the Čorgašávži Formation, not in the Briittagielas Formation. Moreover, the same map demonstrates that, in places, this thick carbonate unit crosses the boundary that divides these two formations (Fig. 3). This indicates that perhaps there is yet no clear understanding as to whether one or two carbonate units are present in the middle part of the KGB succession. 


\section{Available radiometric ages}

The komatiites in the Báhkilvárri Formation have been dated to $2085 \pm 85 \mathrm{Ma}$, using the whole-rock Sm-Nd method (Krill et al., 1985). Marker et al. (2000) reported a $\mathrm{Sm}-\mathrm{Nd}$ model age $\left(\mathrm{T}_{\mathrm{DM}}\right)$ of $3445 \mathrm{Ma}$ for the terrigeneous metasedimentary rocks of the Skuvvanvárri Formation, thus suggesting an Archaean source for the detritus. They also reported that detrital zircons from metasedimentary rocks of the Gollebáiki Formation dated by Secondary Ion Mass Spectrometry (SIMS) at the NORDSIM show a spread of concordant ages between 1971 and $2438 \mathrm{Ma}$ with one grain at $3188 \mathrm{Ma}$. The four youngest grains define an intercept at $1947 \pm 88 \mathrm{Ma}$. In addition, a granodiorite body intruded into the Báhkilvárri amphibolites was dated conventionally by a $\mathrm{U}-\mathrm{Pb}$ technique. In this study, five fractions defined a concordia intercept at 1974 $\pm 8 \mathrm{Ma}$, which provides a minimum depositional age for the Báhkkilvárri Formation (Marker et al., 2000).

\section{Carbonate rocks, sampled localities}

The carbonate unit (CU hereafter) occurring in the Čorgašávži/Briittágielas stratigraphic interval (or in the Gollebáiki Formation of Often (1985)) has been sampled in four different localities designated as profiles 1 to 4 in Figs. 2 and 3.

Profile 1 (samples 1-17) is located in the northeastern corner of the studied area where the CU is exposed in several isolated outcrops. The sampled interval extends over c. $500 \mathrm{~m}$ along strike, and has a visible structural thickness of more than $25 \mathrm{~m}$. The CU is tightly folded and composed of banded, calcite-dolomite-tremolite rocks with numerous $0.5-1 \mathrm{~m}$-thick beds of pale-grey dolomite marbles and rare calcite marbles (Fig. 5A, B).

Profile 2 (samples 18-27) is located in the central part of the studied area where two tightly spaced CUs separated by a plagioclase-mica schist are exposed in several isolated localities. It remains uncertain as to whether these two CUs represent two stratigraphically different intervals or only one duplicated by folding. The CUs are composed mainly of pale-grey, thinly banded dolomite and calcite marbles which, in places, are mylonitised (Fig. $5 \mathrm{C})$. In one case the marble is red coloured.

Profile 3 (samples 28-36) is located in the western part of the studied area and represents the most exposed section of the CU. Samples were collected from a c. $40 \mathrm{~m}$-high cliff (Fig. 5 D). Here, the CU is composed of pink, red and pale-grey dolomite marbles. The marbles show centimetre to decimetre banding with intercalations of thin layers of calc-silicate rocks (Fig. 5E, F).
Profile 4 (samples 37-39) represents the southernmost known locality of the CU (Fig. 2B). This is a road-cut exposing white, banded, calcite marbles in a unit a few metres in thickness.

\section{Analytical methods}

Major and trace elements were analysed by X-ray fluorescence spectrometry (XRF) at the Geological Survey of Norway (NGU), Trondheim, using a PANalytical Axios at $4 \mathrm{~kW}$ X-ray spectrometer. The precision (1s) is typically around $2 \%$ of the major oxide present. Acid-soluble Fe, $\mathrm{Ca}, \mathrm{Mg}$ and $\mathrm{Mn}$ extracted with $10 \%$ cold $\mathrm{HCl}$ acid were analysed by ICP-AES at NGU using a Thermo Jarrell Ash ICP 61 instrument. Detection limits for Fe, $\mathrm{Mg}, \mathrm{Ca}$ and $\mathrm{Mn}$ are 5, 100, 200 and $0.2 \mathrm{ppm}$, respectively. The total analytical uncertainty including element extraction $(1 \sigma)$ is $\pm 10 \%$ rel.

Oxygen and carbon isotope analyses of whole-rock marble samples were carried out at the Scottish Universities Environmental Research Centre, Glasgow, using the phosphoric acid method of McCrea (1950) as modified by Rosenbaum \& Sheppard (1986) for operation at $100^{\circ} \mathrm{C}$. Carbon and oxygen isotope ratios in carbonate constituents of the whole-rock samples were measured on a VG SIRA 10 mass spectrometer. Analyses were calibrated against NBS 19, and precision (1s) for both isotope ratios is better than $\pm 0.2 \%$. Oxygen isotope data for dolomites were corrected using the fractionation factor 1.00913 recommended by Rosenbaum \& Sheppard (1986). The $\delta^{13} \mathrm{C}$ data are reported in per mil (\%o) relative to $\mathrm{V}-\mathrm{PDB}$ and the $\delta^{18} \mathrm{O}$ data in \%o relative to $\mathrm{V}-\mathrm{SMOW}$.

\section{Major and trace element geochemistry, and $\mathrm{C}$ and $\mathrm{O}$ isotope ratios of marbles}

Major and trace element data and $\mathrm{C}$ and $\mathrm{O}$ isotopic values obtained from the marbles of the KGB are presented in Table 1. Geochemical characteristics of the studied carbonate and carbonate-bearing rocks are based on 38 whole-rock analyses (Table 1). Geochemically, all analysed samples obtained from the CU can be divided into four groups: Group 1 - dolomite marbles $(\mathrm{Mg} / \mathrm{Ca}$ (carbonate phase) $=0.44-0.65, \mathrm{MgO} / \mathrm{CaO}_{\text {wr }}$ (whole rock) $=0.48-0.70, \mathrm{n}=22)$; Group 2 - marbles with a mixed calcite-dolomite mineralogy $(\mathrm{Mg} / \mathrm{Ca}$ carb $=0.003-0.34$, $\left.\mathrm{MgO} / \mathrm{CaO}_{\text {wr }}=0.19-0.37, \mathrm{n}=4\right)$; Group 3 - dolomitecalcite-tremolite rocks $\left(\mathrm{Mg} / \mathrm{Ca}_{\text {carb }}=0.18-0.35, \mathrm{MgO} /\right.$ $\left.\mathrm{CaO}_{\text {wr }}=0.40-0.94, \mathrm{n}=4\right)$; and Group 4 - calcite marbles $\left(\mathrm{Mg} / \mathrm{Ca}_{\text {carb }}=0.003-0.13, \mathrm{MgO} / \mathrm{CaO}_{\mathrm{wr}}=0.02-0.16, \mathrm{n}=8\right)$. A large discrepancy between $\mathrm{Mg} / \mathrm{Ca}_{\text {carb }}$ and $\mathrm{MgO} / \mathrm{CaO}_{\text {wr }}$ ratios is observed in Group 2 rocks in Profile 1 (samples 6-8) and Group 3 rocks in Profile 2 (samples 19 and 24; 


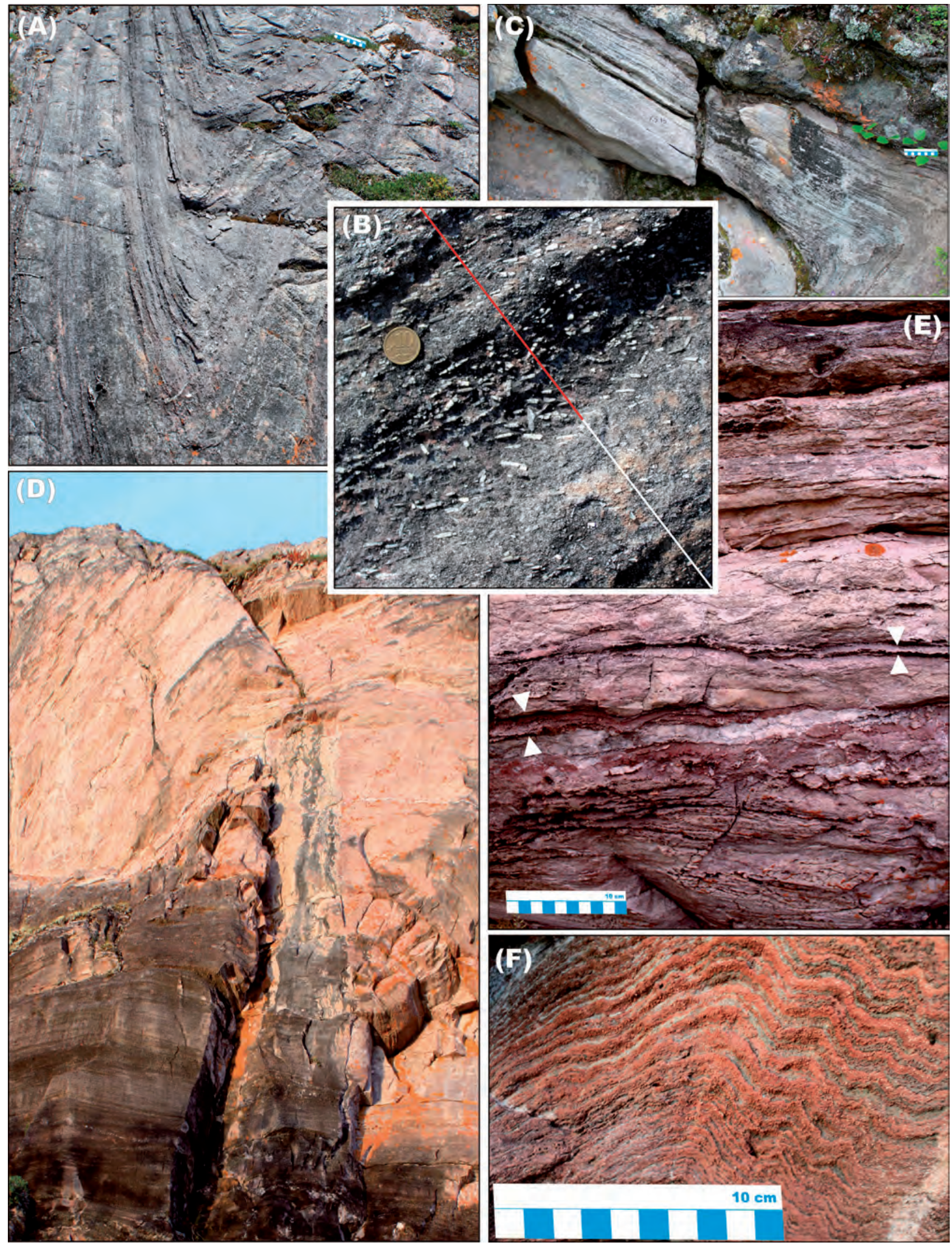

Figure 5. Images illustrating some main sedimentological features of carbonate rocks of the CUs in the KGB. (A) A natural outcrop of tightly folded, thinly banded, calcite marble from Profile 1. (B) A photograph of banded dolomite marble composed of alternating tremolite-poor (white line) and tremolite-rich (red line) bands from Profile 1; a coin for scale is $1 \mathrm{~cm}$ in diameter. (C) A small vertical cliff exposing a mylonitised, calcite marble from Profile 2. (D) A c. 40 m-high cliff exposing dolomite marbles from Profile 3. (E) Pink and white dolomite marble with thin interlayers of red calc-silicate bands (white arrowed). (F) Thin alternation of dolomite (pale pink) and calc-silicate (pale grey) bands. Scale-bars in (A), (C), (E) and (F) with cm divisions. 


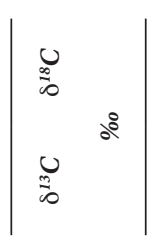

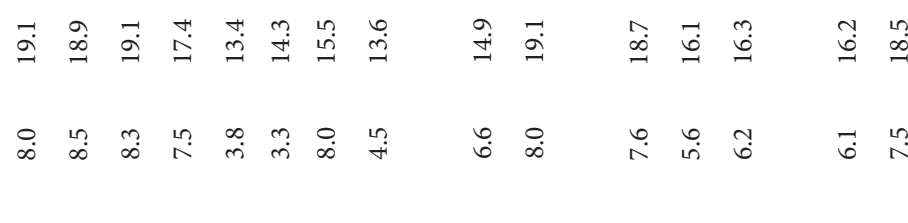

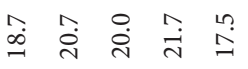

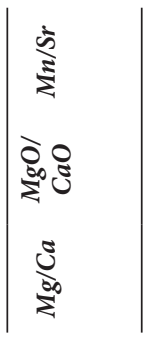

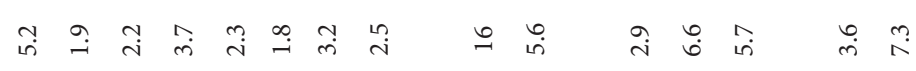

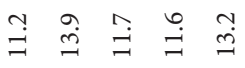

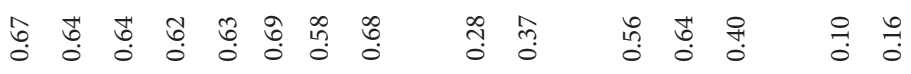

$\sim-\infty \stackrel{\infty}{\wedge}$

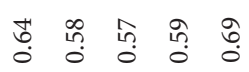

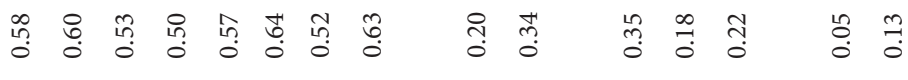

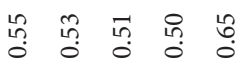

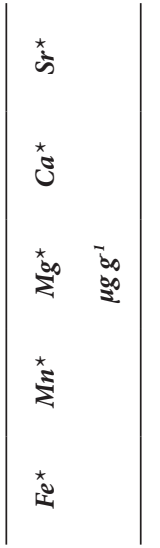

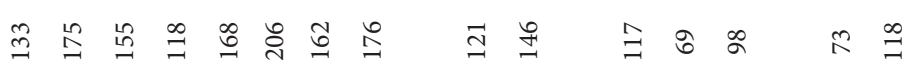

은 in 운

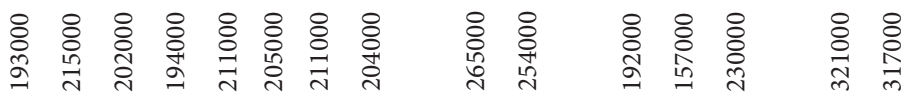

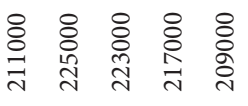

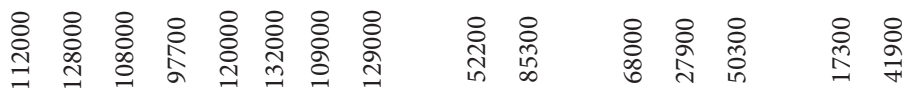

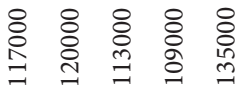

\&

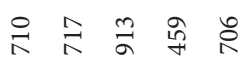

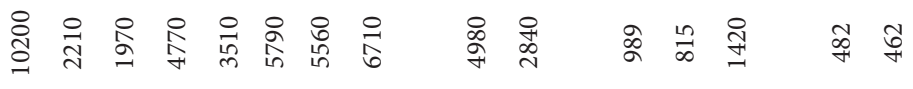

기요ำ

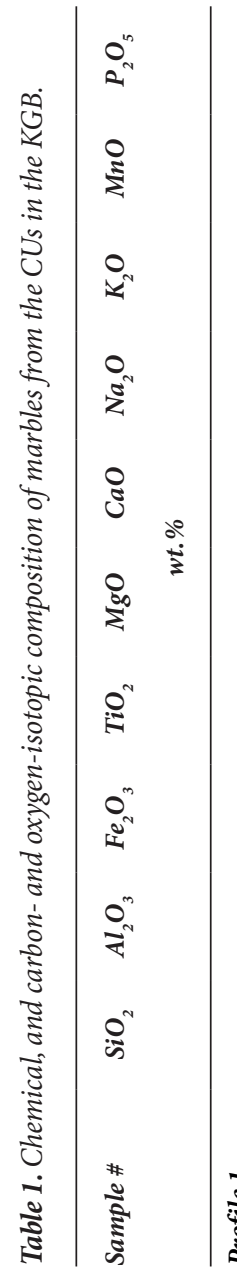

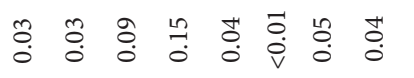

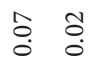

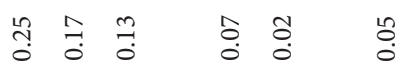

苍

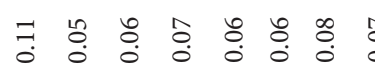

$\overrightarrow{0}$

$\stackrel{\circ}{\circ}:$

范苛递

ت্:

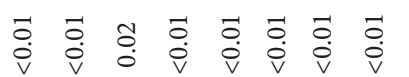

$\overrightarrow{0} \cdot \overrightarrow{0}$

$\stackrel{n}{0} \stackrel{0}{0} 0$

ज्ञ

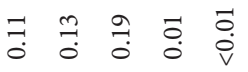

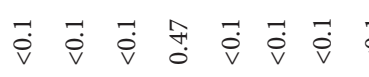

$\overrightarrow{0} \cdot \overrightarrow{0}$

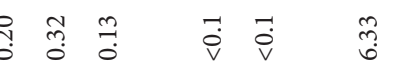

$\vec{i} \overrightarrow{\dot{v}} \overrightarrow{\dot{v}} \overrightarrow{\dot{v}} \overrightarrow{\dot{v}}$

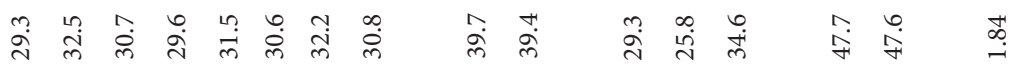

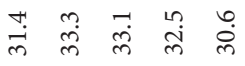

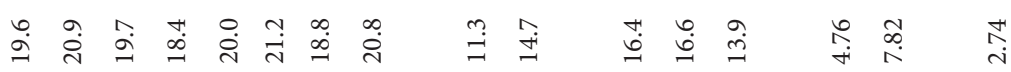

芒

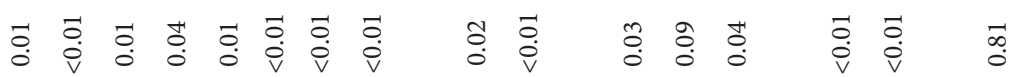

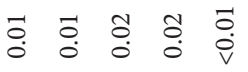

品

$\vec{b}$ 송

品

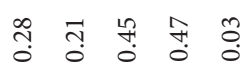

苻

ঢ.

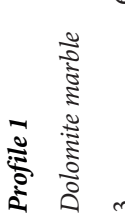
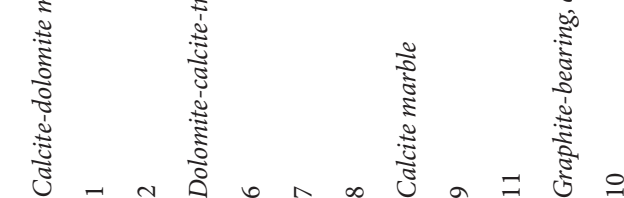

है 


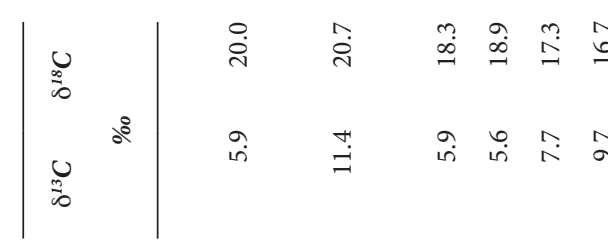

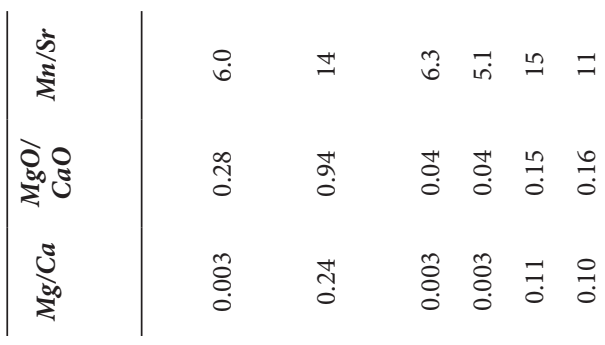

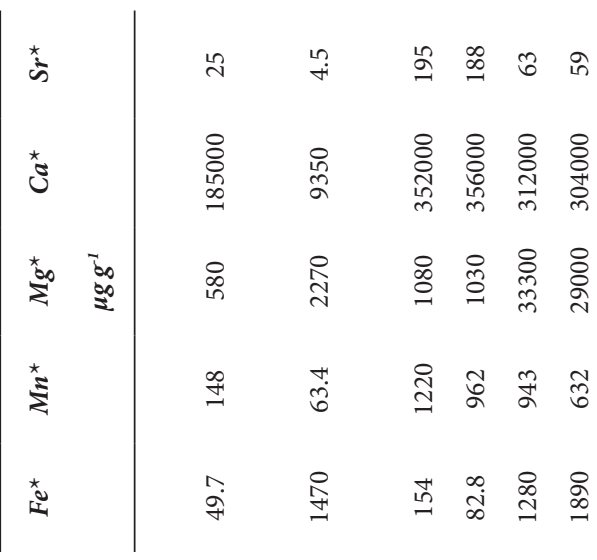

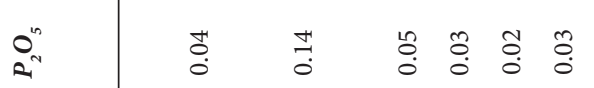

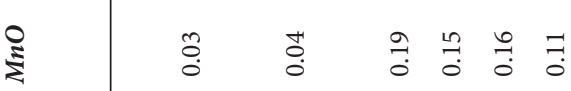

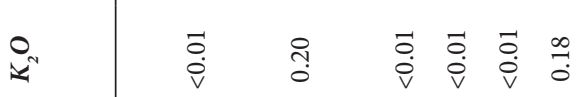

$\begin{array}{lllllll}\dot{u}^{n} & \vec{i} & \vec{b} & \overrightarrow{0} & \overrightarrow{0} & \vec{i} & \overrightarrow{\dot{v}}\end{array}$

\& वे में

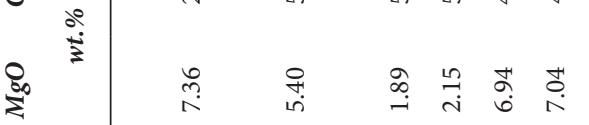

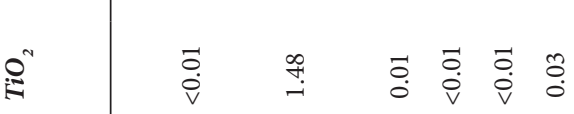

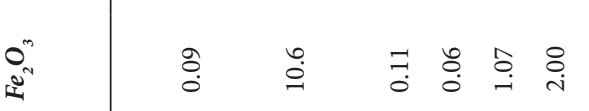

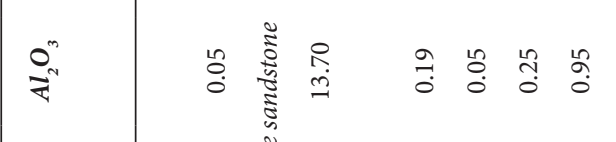

ग)

离

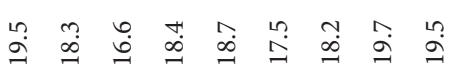

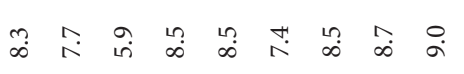

F

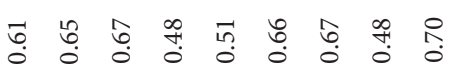

भก:

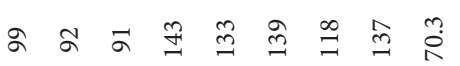

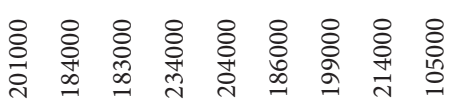

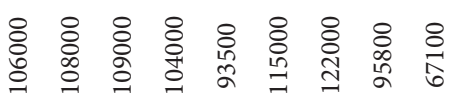

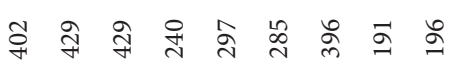

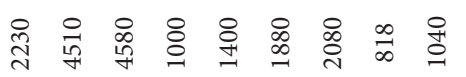

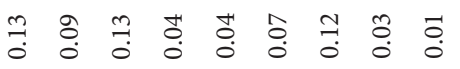

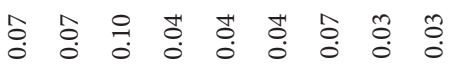

苛 華

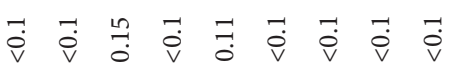

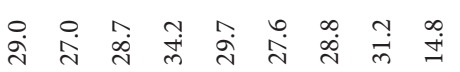

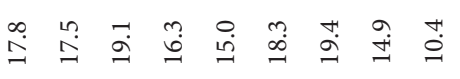

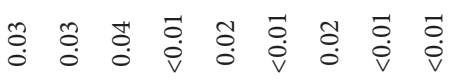

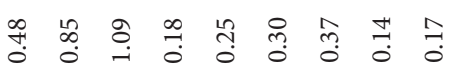

药 点

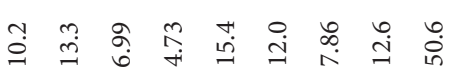

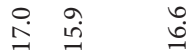

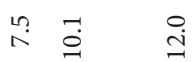

$\infty \stackrel{\infty}{\circ} \stackrel{\infty}{\circ}$

$\stackrel{0}{0} \stackrel{0}{0} \quad \frac{0}{0}$

$\stackrel{0}{0} \stackrel{0}{0} \quad \stackrel{0}{0}$

$\infty 2 \stackrel{2}{\infty}$

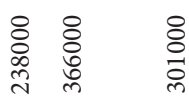

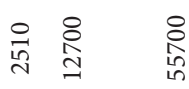

ब용 त्र

岀

:

웅

룡

$\overrightarrow{\dot{v}} \overrightarrow{\dot{v}} \quad \overrightarrow{\dot{v}}$

ले कि में

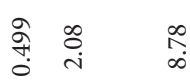

$\begin{array}{lll}\overrightarrow{0} & \overrightarrow{0} & \overrightarrow{0} \\ \dot{0} & 0\end{array}$

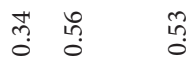

궁

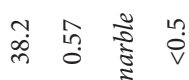

$\frac{5}{5}$

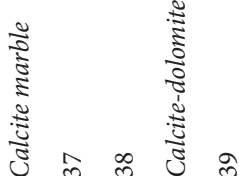


Table 1). These five samples plot well above a best fit-line for other samples in a $\mathrm{Mg} / \mathrm{Ca} a_{\text {carb }}-\mathrm{MgO} / \mathrm{CaO}_{\text {wr }}$ cross plot (Fig. 6A).

The carbonate and carbonate-bearing rocks have a variable $\mathrm{SiO}_{2}$ content ranging from $<0.5$ to $54 \mathrm{wt} . \%$. All Group 1, 2 and 3 marbles, having $\mathrm{SiO}_{2}$ contents over 1 wt.\%, contain a variable amount of tremolite. Abundances of $\mathrm{Al}_{2} \mathrm{O}_{3}$ are below 1 wt.\% with two exceptions (2.6 and 13.7 wt.\%; samples 7 and 24). The rock with the highest $\mathrm{SiO}_{2}$ and $\mathrm{Al}_{2} \mathrm{O}_{3}$ content (sample 24) is also rich in $\mathrm{Na}_{2} \mathrm{O}$ (6.6 wt.\%). It represents a carbonate-bearing, albite sandstone, which is somewhat similar in composition to another albite sandstone, though graphite rich (sample $10, \mathrm{Na}_{2} \mathrm{O}=6.3$ wt.\%), found in the $\mathrm{CU}$ in Profile 1 (Table 1). The rest of the rocks have $\mathrm{Na}_{2} \mathrm{O}$ abundances commonly below 0.1 wt. $\%$ with a few exceptions $(0.11-0.47$ wt.\%, $\mathrm{n}=6)$. All rocks are low in $\mathrm{K}_{2} \mathrm{O}(<0.01-0.2$ wt.\% $)$ and have low to moderate abundances of Sr (25-206 $\mathrm{ppm} ; 110 \mathrm{ppm}$ on average). The $\mathrm{Mn} / \mathrm{Sr}$ ratio is generally low $(6.1 \pm 4, \mathrm{n}=37$, with one outlier at 48 in sample 39).

All carbonate and carbonate-bearing rocks of the $\mathrm{CU}$ are rich in ${ }^{13} \mathrm{C}$. Both the $\delta^{13} \mathrm{C}$ and the $\delta^{18} \mathrm{O}$ values show significant fluctuations. $\delta^{13} \mathrm{C}$ ranges between +3.3 and $+12.9 \%$ $(+8.1 \pm 2.4 \%, \mathrm{n}=38)$, whereas the $\delta^{18} \mathrm{O}$ values fluctuate between 13.4 and $21.7 \% 0(+17.8 \pm 2 \%, \mathrm{n}=38)$. The lowest three $\delta^{18} \mathrm{O}$ values of $13.4-14.3 \%$ are coupled with the lowest ${ }^{13} \mathrm{C}$ values of +3.3 to $+4.5 \%$ o (samples 13,14 and $16)$.

If considered either altogether or at the level of individual profiles, neither $\delta^{13} \mathrm{C}$ nor $\delta^{18} \mathrm{O}$ values show any significant correlation with $\mathrm{SiO}_{2}$ abundances and $\mathrm{Mn} / \mathrm{Sr}$ ratios. If the analyses are considered altogether, there is a significant positive correlation between $\delta^{13} \mathrm{C}$ and $\delta^{18} \mathrm{O}$ values
$(+0.58,>99 \%, \mathrm{n}=38$; Fig. 6B). This correlation becomes stronger if only Groups 1 and 3 rocks are considered $(+0.89,>99 \%, \mathrm{n}=25)$. If the three samples with the lowest $\delta^{13} \mathrm{C}$ and $\delta^{18} \mathrm{O}$ values are excluded, there is also a positive correlation between $\delta^{13} \mathrm{C}$ values and $\mathrm{Mg} / \mathrm{Ca}$ carb ratios $(+0.37,>95 \%, \mathrm{n}=35$, Fig. $6 \mathrm{C})$. This correlation appears to be stronger if Group 1 and Group 2 rocks are considered separately $(+0.81,99 \%, \mathrm{n}=12$; and $+0.86,>99 \%, \mathrm{n}=11$, respectively). Similar correlations are observed between $\delta^{13} \mathrm{C}$ values and $\mathrm{Mg} / \mathrm{Ca}$ wr ratios.

\section{Geochemical screening of $C$ isotopes for post-depositional alteration}

In diagenetic and metamorphic processes, the $\mathrm{Mn}$ and Sr contents in carbonates are commonly partially shifted towards equilibrium with the post-depositional fluids, and may lead to $\mathrm{Sr}$ depletion and $\mathrm{Mn}$ enrichment (Veizer, 1983; Kaufman \& Knoll, 1995). Consequently, Mn and Sr abundances can serve as possible tools for calibration of the relative diagenetic rank of sequences (Brand \& Veizer, 1980; Derry et al., 1992).

In general, diagenetic, hydrothermal and metamorphic fluids have high water/rock ratios for oxygen, but low water/rock ratios for carbon (e.g., Hudson, 1977; Banner \& Hanson, 1990; Nabelek, 1991; Land, 1992; Jacobsen \& Kaufman, 1999). Consequently, as a rule, the carbon system is effectively buffered by the dissolving carbonate precursor; hence, it is far more resilient during postdepositional, open-system recrystallisation (excluding organic diagenesis) with respect to the oxygen system. The latter is commonly much more easily affected by

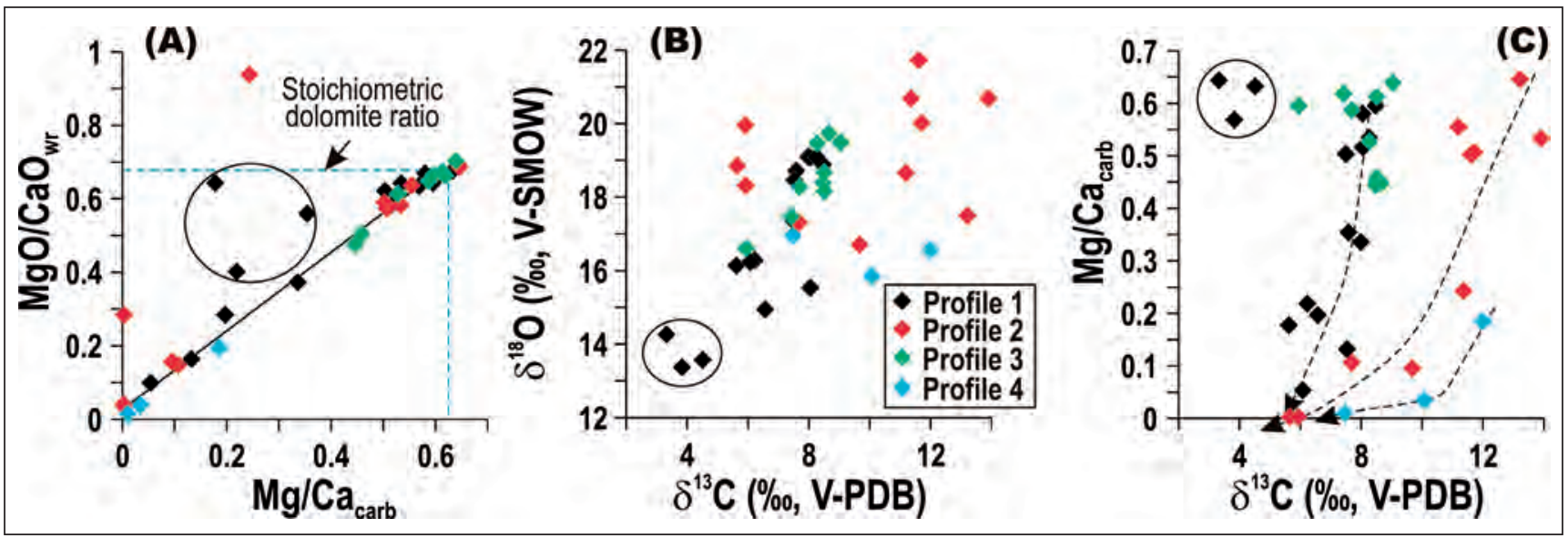

Figure 6. Various cross-plots demonstrating C-isotope and geochemical variability in carbonate rocks from different profiles. $(A) \mathrm{Mg}_{\mathrm{C}} \mathrm{Ca}{ }_{\text {carb }}$ versus $\mathrm{MgO} / \mathrm{CaO}$ cross-plot; three samples from Profile 1 (encircled black diamonds) and two samples from Profile 2 (red diamonds) above the best-fit line (solid black) experienced quartz-dolomite metamorphic reaction, formation of tremolite and degassing of $\mathrm{CO}_{2}$ enriched in ${ }^{13} \mathrm{C}$ and ${ }^{18} \mathrm{O}$. (B) $\delta^{13} \mathrm{C}$ versus $\delta^{18} \mathrm{O}$ cross-plot illustrating a positive correlation between the two values in marbles from Profiles 1 and 3 ; the most altered samples from Profile 1 are encircled. (C) $M g / C a_{\text {carb }}$ versus $\delta^{13} \mathrm{C}$ cross-plot; dashed lines show apparent alteration trends. 
exchangeable oxygen derived from either meteoric water or interstitial fluids at elevated temperatures (e.g., Fairchild et al., 1990). In some cases, carbonate rocks that experienced a significant deformation may exhibit depletion in both oxygen and carbon isotope values (e.g., Guerrera et al., 1997). In the following discussion, oxygen isotope values and $\delta^{13} \mathrm{C}-\delta^{18} \mathrm{O}$ cross-plots have been utilised for tracking the degree of post-depositional recrystallisation.

For the studied carbonate rocks the $\delta^{13} \mathrm{C}-\delta^{18} \mathrm{O}$ cross-plot shows significant positive correlation, particularly for Groups 1 and 3 carbonates (Fig. 6B), hence suggesting that both isotope systems have been affected by alteration. This is also supported by variable $\mathrm{Mn} / \mathrm{Sr}$ ratios of these rocks (Table 1 ). The $\delta^{13} \mathrm{C}-\delta^{18} \mathrm{O}$ cross-plot suggests that the three samples with lowest $\delta^{13} \mathrm{C}$ and $\delta^{18} \mathrm{O}$ should be excluded from further consideration as they are definitely severely altered. A large discrepancy between $\mathrm{Mg} / \mathrm{Ca}_{\text {carb }}$ and $\mathrm{MgO} / \mathrm{CaO}_{\text {wr }}$ ratios observed in these three samples (Fig. 6A) and the presence of tremolite is indicative of an alteration process associated with a decarbonation reaction and removal of $\mathrm{CO}_{2}$ enriched in ${ }^{13} \mathrm{C}$ and ${ }^{18} \mathrm{O}$ :

$6\left[\mathrm{Ca}, \mathrm{Mg}\left(\mathrm{CO}_{3}\right)_{2}\right]+8 \mathrm{SiO}_{2}+2 \mathrm{H}_{2} \mathrm{O} \rightarrow$

$\mathrm{Mg}_{6}\left[\mathrm{Si}_{8} \mathrm{O}_{20}\right](\mathrm{OH})_{4}+6 \mathrm{CaCO}_{3}+6 \mathrm{CO}_{2}$

The aforementioned volatilisation reaction could have been the mechanism influencing the $\delta^{13} \mathrm{C}$ and $\delta^{18} \mathrm{O}$ compositions of residual dolomite and newly formed calcite (Shieh \& Taylor, 1969; Bucher \& Frey, 2002), and could explain the observed depletion in ${ }^{18} \mathrm{O}$ and ${ }^{13} \mathrm{C}$ with respect to the least altered samples.

The negative correlation of $\delta^{13} \mathrm{C}$ values with both $\mathrm{Mg} /$ $\mathrm{Ca}_{\text {wr }}$ and $\mathrm{Mg} / \mathrm{Ca} a_{\text {carb }}$ ratios (Fig. $6 \mathrm{C}$ ) suggests that a dedolomitisation process has been involved in the depletion of carbonate rocks in ${ }^{13} \mathrm{C}$. This is particularly the case for Groups 1, 2 and 4 carbonates; completely dedolomitised rocks (e.g., calcite marbles) are depleted with respect to the dolomite marbles by 3-8\%o (Fig. 6C). If the $\delta^{13} \mathrm{C}$ values of the least dedolomitised samples are considered to represent the best available proxy for the isotopic composition of seawater, then two different rock assemblages can be recognised. The first is characterised by the least-altered $\delta^{13} \mathrm{C}$ values of +8 to $+9 \%$ and includes marbles from Profiles 1 and 3 (Fig. 6C). The second assemblage has least-altered $\delta^{13} \mathrm{C}$ values of $c .+12$ to $+14 \%$ and comprises marbles from Profiles 2 and 4 .

\section{Implication of $\delta^{13} \mathrm{C}$ values of the CU of the KGB for depositional age constraint}

The Sm-Nd, whole-rock, imprecise date of $2085 \pm 85 \mathrm{Ma}$ obtained from the komatiites in the Báhkilvárri Formation (Krill et al., 1985), and the U-Pb zircon age of 1974 $\pm 8 \mathrm{Ma}$ obtained from the granodiorite intruded into the Báhkilvárri amphibolites (Marker et al., 2000) provide the minimum depositional age for the supracrustal rocks of the KGB (Fig. 4A). The U-Pb date of $1947 \pm 88 \mathrm{Ma}$ on detrital zircons from the Gollebáiki Formation (Marker et al., 2000) sets the upper age limit.

A further constraint on the deposition of $\mathrm{CU}$ marbles and associated rocks can be provided by means of the carbon isotope chemostratigraphy. The Early Palaeoproteozoic history of the Earth's evolution is marked by the earliest known perturbation of the global carbon cycle (Baker \& Fallick, 1989a, b) known now as the Lomagundi-Jatuli isotopic event (reviewed in Melezhik et al., 2013b). The event is expressed as a global-scale positive excursion of carbonate carbon isotopes in sedimentary carbonates (Fig. 7). Recent compilations of all available radiometric dates suggest that the excursion very likely occurred between 2300-2220 and 2060 Ma (Martin \& Condon, 2013; Martin et al., 2013, 2014). However, in the Fennoscandian Shield, the Lomagundi-Jatuli isotopic event has been confidently constrained in several places between c. 2220 and $2060 \mathrm{Ma}$ (Karhu, 2005; Melezhik et al., 2007; Fig. 7). Projection of the least-altered carbonisotopic values on to the $\delta^{13} \mathrm{C}$ reference curve (Fig. 7) suggests that the CUs of the KGB were apparently deposited between 2220 and 2110 (Profiles 2 and 4) and 2220 and $2140 \mathrm{Ma}$ (Profiles 1 and 3). The obtained chemostratigraphic ages partially overlap within error with the Sm$\mathrm{Nd}$ date of $2085 \pm 85 \mathrm{Ma}$; however, they definitely cannot be younger than $2060 \mathrm{Ma}$, and very likely are older than 2110-2140 Ma.

We consider that the obtained apparent depositional ages of the protolith of the studied marbles are applicable to the entire belt stratigraphy despite uncertainties involved in correlation between its northern and southern parts. The obtained C-isotopic data also allow correlation of the studied carbonate rocks with ${ }^{13} \mathrm{C}$-rich dolostones $\left(\delta^{13} \mathrm{C}=+7.4 \pm 0.7 \% 0, \mathrm{n}=51\right.$; Melezhik et al., 2015) constituting the Kvenvik formation, which occurs in the Alta-Kvænangen Tectonic Window near Alta, c. $80 \mathrm{~km}$ west of the northern KGB. In both locations, the carbonate rocks are markedly enriched in ${ }^{13} \mathrm{C}$ and record the Lomagundi-Jatuli positive excursion of carbonate carbon isotopes in sedimentary carbonates. However, high$\delta^{13} \mathrm{C}$ carbonate rocks have not yet been found in either the Kautokeino Greenstone Belt (Melezhik, unpublished data) or the Repparfjord Tectonic Window northeast of Alta (Melezhik \& Fallick, 1996). 


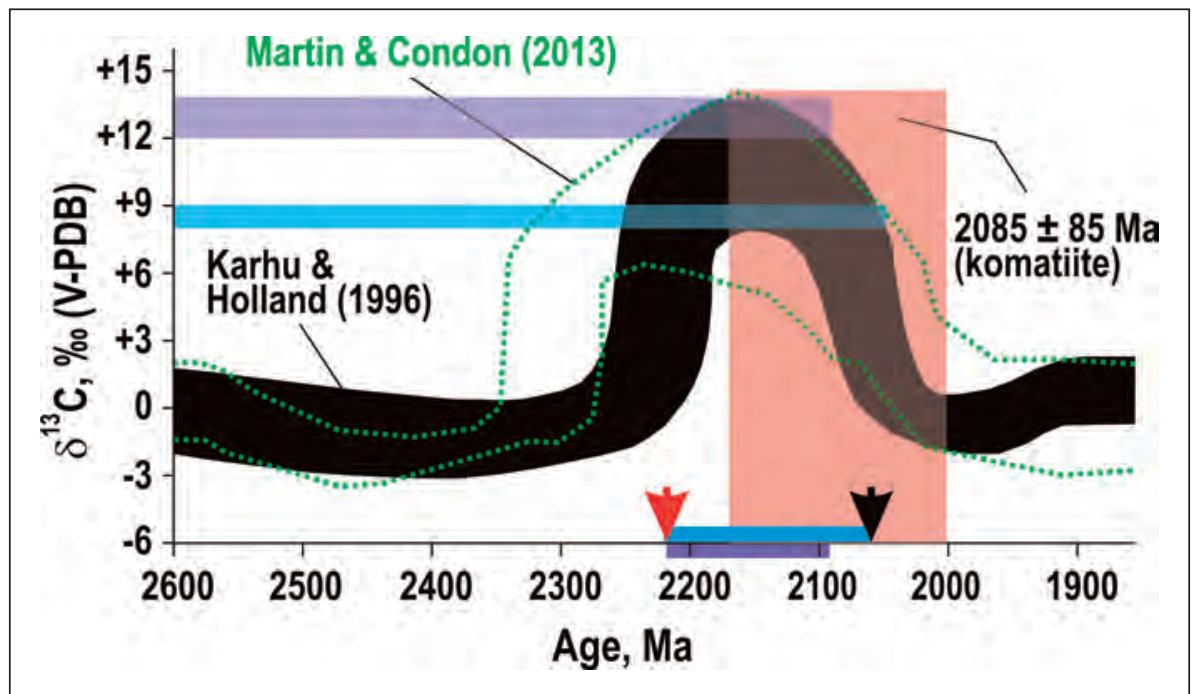

Figure 7. A $\delta^{13} \mathrm{C}$ variability in Palaeoproterozoic carbonate formations based on U-Pb and Re-Os data. Modified after Karhu \& Holland (1996) and Martin \& Condon (2013). The long horizontal violet and blue bars represent the range of the least altered $\delta^{13} \mathrm{C}$ values in marbles from Profiles 2 and 4, and Profiles 1 and 3, respectively. Pink vertical bar denotes the Sm-Nd radiometric age for the Báhkilvárri Formation komatiites. The red arrow indicates the start of deposition of ${ }^{13} \mathrm{C}$-rich carbonates reported from Precambrian rocks of the Fennoscandian Shield, hence setting the lower age limit for accumulation of the ${ }^{13} \mathrm{C}$-rich carbonates of the KGB. The black arrow indicates the termination of deposition of the Lomagundi-Jatuli isotopic event in the Fennoscandian Shield and worldwide, thus providing the lower age limit for the deposition of the CUs. The violet and blue horizontal bars placed along the age axis denote the projection of the apparent depositional timerange of carbonate rocks from Profiles 2 and 4, and from Profiles 1 and 3, respectively.

\section{Conclusions}

1. The marble unit occurring in the middle part of the tectonostratigraphic succession of the Karasjok Greenstone Belt shows anomalously high $\delta^{13} \mathrm{C}_{\text {carb }}$ values and records a global positive excursion of carbonate carbon isotope ratios in sedimentary carbonates known as the Lomagundi-Jatuli isotopic event.

2. The marble unit sampled in the northern part of the belt contains two isotopically different assemblages occurring in geographically different locations.

3. Carbon isotope chemostratigraphy constrains the deposition of these two ${ }^{13} \mathrm{C}$-rich carbonate assemblages to between $<2220$ and $2110 \mathrm{Ma}\left(\delta^{13} \mathrm{C}_{\text {carb }}=+12\right.$ to $+14 \% 0)$ and 2220 and $2140 \mathrm{Ma}\left(\delta^{13} \mathrm{C}_{\text {carb }}=+8\right.$ to $+9 \%$ ).

Acknowledgements. Carbon and oxygen isotope analyses were supported by the Scottish Universities (AEF). Fieldwork, sample preparation, XRF and ICP-AES analyses were supported by the MINN project (VAM, AS and BD). Mogens Marker is acknowledged for a helpful discussion on published radiometric dates. Constructive comments and criticism were gratefully received from the official reviewers, Morten Often and Alcides Nobrega Sial.

\section{References}

Baker, A.J. \& Fallick, A.E. 1989a: Evidence from Lewisian limestone for isotopically heavy carbon in two-thousand-million year-old sea water. Nature 337, 352-354

Baker, A.J. \& Fallick, A.E. 1989b: Heavy carbon in two-billion-year old marbles from Lofoten-Vesterålen, Norway: implications for the Precambrian carbon cycle. Geochimica et Cosmochimica Acta 53, 1111-1115.

Banner, J.L. \& Hanson, G.N. 1990: Calculation of simultaneous isotopic and trace element variations during water-rock interaction with applications to carbonate diagenesis. Geochimica et Cosmochimica Acta 54, 3123-3137.

Braathen, A. \& Davidsen, B. 2000: Structure and stratigraphy of the Palaeoproterozoic Karasjok Greenstone Belt, north Norway regional implications. Norsk Geologisk Tidsskrift 80, 33-50.

Brand, U. \& Veizer, J. 1980: Chemical diagenesis of a multicomponent carbonate system - 1: Trace elements. Journal of Sedimentary Petro$\log y 50,1219-1236$.

Bucher, K. \& Frey, M. 2002: Petrogenesis of Metamorphic Rocks. Springer-Verlag, Berlin, $341 \mathrm{pp}$.

Bugge, J.A.W. 1978: Norway. In Bowie, S.H.U., Kvalheim, A. \& Haslarn. H.W. (eds.): Mineral Deposits of Europe, Vol. I, Northwest Europe. Institute of Mining and Metallurgy, London, pp. 199-249.

Crowder, D.F. 1959: The Precambrian schists and gneisses of Lakselv Valley, northern Norway. Norsk Geologisk Tidsskrift 205, 17-40.

Davisen, B. 1994: Stratigrafi, petrologi og geokjemi med vekt på komatiittiske bergarter innen den nordligste del av Karasjok grønnsteinsbelte, Brennelv, Finnmark. Cand. Scient thesis, University of Tromsø, 380 pp. (In Norwegian).

Derry, L.A., Kaufman, A.J. \& Jacobsen, S.B. 1992: Sedimentary cycling and environmental change in the Late Proterozoic: evidence from stable and radiogenic isotopes. Geochimica et Cosmochimica Acta $56,1317-1329$. 
Eilu, P. 1994: Hydrothermal alteration in volcano-sedimentary rocks in the Central Lapland Greenstone Belt, Finland. Geological Survey of Finland Bulletin 374, 1-145.

Elvebakk, G., Krill, A.G., Often, M. \& Henriksen. H. 1985: Early Proterozoic shallow-marine albite-rich sandstone in the Karasjok Greenstone Belt, Norwav. Norges geologiske undersøkelse Bulletin 403, 113-118.

Ettner, D.C., Bjørlykke, A. \& Andersen, T. 1994: A fluid inclusion and stable isotope study of the Proterozoic Bidjovagge $\mathrm{Au}-\mathrm{Cu}$ deposit, Finnmark, northern Norway. Mineralium Deposita 29, 16-129.

Fairchild, I.J., Marshall, J.D. \& Bertrand-Sarafati, J. 1990: Stratigraphic shifts in carbon isotopes from Proterozoic stromatolitic carbonates (Mauritania): Influences of primary mineralogy and diagenesis. American Journal of Science 290-A, 46-79.

Frietsch, R., Tuisku, P., Martinsson, O. \& Perdahl, J.-A. 1997: Early Proterozoic $\mathrm{Cu}-(\mathrm{Au})$ and $\mathrm{Fe}$ ore deposits associated with regional $\mathrm{Na}-\mathrm{Cl}$ metasomatism in northern Fennoscandia. Ore Geology Reviews 12, 1-34.

Guerrera, A., Peacock, S.M. \& Knauth, L.P. 1997: Large ${ }^{18} \mathrm{O}$ and ${ }^{13} \mathrm{C}$ depletions in greenschist facies carbonate rocks, western Arizona. Geology 25, 943-946.

Henriksen. H. 1983: Komatiitic chlorite-amphibole rocks and mafic metavolcanics from the Karasjok Greenstone Belt, Finnmark, northern Norway. A preliminary report. Norges geologiske undersøkelse 382, 131-184.

Hudson, J.D. 1977: Stable isotopes and limestone lithification. Journal of the Geological Society of London 133, 637-660.

Jacobsen, S.B. \& Kaufman, A.J. 1999: The Sr, C and O isotopic evolution of Neoproterozoic seawater. Chemical Geology 161,37-57.

Karhu J. A., 2005: Paleoproterozoic carbon isotope excursion. In Lehtinen, M., Nurmi, P. A., \& Rämö, O.T. (eds.): Precambrian Geology of Finland-Key to the Evolution of the Fennoscandian Shield. Elsevier, Amsterdam, pp. 669-680.

Karhu, J.A. \& Holland, H.D. 1996: Carbon isotopes and the rise of atmospheric oxygen. Geology 24, 867-879.

Kaufman, A.J. \& Knoll, A.H. 1995: Neoproterozoic variations in the C-isotopic composition of seawater: stratigraphic and biogeochemical implications. Precambrian Research 73, 27-49.

Koistinen, T., Stephens, M.B., Bogatchev, V., Nordgulen, Ø., Wenneström, M. \& Korhonen, J. 2001: Geological Map of the Fennoscandian Shield, Scale 1:2,000,000. Espoo, Trondheim, Uppsala, Moscow.

Krill, A.G., Bergh, S., Lindahl, I., Mearns, E.W., Often, M., Olerud, S., Olesen, O., Sandstad, J.S., Siedlecka, A. \& Solli, A. 1985: Rb-Sr, U$\mathrm{Pb}$ and $\mathrm{Sm}-\mathrm{Nd}$ isotopic data from Precambrian rocks of Finnmark. Norges geologiske undersøkelse Bulletin 403, 37-54.

Kyläkoski, M., Hanski, E. \& Huhma, H. 2012: The Petäjäskoski Formation, a new lithostratigraphic unit in the Paleoproterozoic Peräpohja Belt, northern Finland. Geological Society of Finland Bulletin 84, $85-120$.

Land, L.S. 1992: The dolomite problem: stable and radiogenic isotope clues. In Clauer, N. \& Chaudhuri, S. (eds): Isotopic Signatures and Sedimentary Records. Springer-Verlag, pp. 49-68.

Mänttäri, M. 1995: Lead isotope characteristics of epigenetic gold mineralization in the Palaeoproterozoic Lapland greenstone belt, northern Finland. Geological Survey of Finland Bulletin 381, 70 pp.

Marker, M., Kaulina, T.V. \& Daly, J.S. 2000: New evidence for the Proterozoic evolution of the Tanaelv and Karasjok belts based on $\mathrm{Sm}-\mathrm{Nd}$ data and recent $\mathrm{U}-\mathrm{Pb}$ NORDSIM and TIMS dating from Finnmark, Norway. SVEKOLAPKO an EUROPROBE project, 5th Workshop, Lammi, Finland, 2-5. November 2000, University of Oulu, Department of Geophysics, Report NO. 23, p. 52.

Martin A.P. \& Condon, D.J. 2013: Review of available radiometric ages constraining the Lomagundi-Jatuli positive isotopic excursion of carbonate carbon. In Melezhik, V.A., Kump, L.R., Fallick, A.E., Strauss, H., Hanski, E.J., Prave, A.R. \& Lepland, A. (eds.): Reading the Archive of Earth's Oxygenation. Volume 3: Global Events and the Fennoscandian Arctic Russia - Drilling Early Earth Project. Frontiers in Earth Sciences. Springer, Heidelberg, pp. 1115-1116.
Martin, A.P. Condon, D.J., Prave A.R., Melezhik, V.A., Lepland, A. \& Fallick, A.E. 2013: Dating the termination of the Palaeoproterozoic Lomagundi-Jatuli carbon isotopic event in the North Transfennoscandian Greenstone Belt. Precambrian Research 224, 160-168.

Martin, A.P., Condon, D.J., Prave, A.R. \& Lepland, A. 2014: A review of temporal constraints for the Palaeoproterozoic large, positive carbonate carbon isotope excursion (the Lomagundi-Jatuli Event). Earth-Science Reviews 127, 242-261.

McCrea, J.M. 1950: On the isotopic chemistry of carbonates and a paleotemperature scale. Journal of Chemical Physics 18, 849-857.

Melezhik, V.A. \& Fallick, A.E. 1996: A widespread positive $\delta^{13} \mathrm{C}_{\text {carb }}$ anomaly at around 2.33-2.06 Ga on the Fennoscandian Shield: a paradox. Terra Nova 8, 141-157.

Melezhik, V.A., Huhma, H., Condon, D.J., Fallick, A.E. \& Whitehouse, M.J. 2007: Temporal constraints on the Paleoproterozoic Lomagundi-Jatuli carbon isotopic event, Geology 35, 655-658.

Melezhik, V.A., Medvedev, P.V. \& Svetov, S.A. 2012: The Onega Basin. In Melezhik, V.A., Prave, A.R., Hanski, E.J., Fallick, A.E., Lepland, A., Kump, L.R. \& Strauss, H. (eds.): Reading the Archive of Earth's Oxygenation. Volume 1: The Palaeoproterozoic of Fennoscandia as Context for the Fennoscandian Arctic Russia - Drilling Early Earth Project. Frontiers in Earth Sciences. Springer, Heidelberg, pp. 387-490.

Melezhik, V.A., Fallick, A.E., Filippov, M.M., Deines, Y.E., Črne, A.E., Lepland, A., Brasier, A.T. \& Strauss, H. 2013a: Giant Palaeoproterozoic petrified oil field in the Onega Basin. In Melezhik, V.A., Kump, L.R., Fallick, A.E., Strauss, H., Hanski, E.J., Prave, A.R. \& Lepland, A. (eds.): Reading the Archive of Earth's Oxygenation. Volume 3: Global Events and the Fennoscandian Arctic Russia - Drilling Early Earth Project. Frontiers in Earth Sciences. Springer, Heidelberg, pp. 1202-1212.

Melezhik, V.A., Fallick, A.E., Martin, A.P., Condon, D.J., Kump, L.R., Brasier, A.T. \& Salminen, P.E. 2013b: The Palaeoproterozoic perturbation of the global carbon cycle: the Lomagundi-Jatuli isotopic event. In Melezhik, V.A., Kump, L.R., Fallick, A.E., Strauss, H., Hanski, E.J., Prave, A.R. \& Lepland, A. (eds.): Reading the Archive of Earth's Oxygenation. Volume 3: Global Events and the Fennoscandian Arctic Russia - Drilling Early Earth Project. Frontiers in Earth Sciences. Springer, Heidelberg, pp. 1111-1150.

Melezhik, V.A., Bingen, B., Sandstad, J.S., Pokrovsky, B.G., Solli, A. \& Fallick, A.E. 2015: Sedimentary-volcanic successions of the AltaKvænangen Tectonic Window in the Northern Norwegian Caledonides: Multiple constraints on deposition and correlation with the Fennoscandian Shield. Norwegian Journal of Geology 95, 245-284. http://dx.doi.org/10.17850/njg95-3-01.

Nabelek, P.I. 1991: Stable isotope monitors. In Kerrick, D.M. (ed.): Contact Metamorphism. Reviews in Mineralogy 26, pp. 395-435.

Often, M. 1985: The Early Proterozoic Karasjok Greenstone Belt, Norway: a preliminary description of lithology, stratigraphy and mineralization. Norges geologiske undersøkelse Bulletin 403, 75-88.

Olerud, S. 1988: Davidite-loveringite in early Proterozoic albite felsites in Finnmark, north Norway. Mineralogical Magazine 52, 400-402.

Pharaoh, T.C. 1981: Preliminary report on the geology of the northern part of the Lakselv valley, Finnmark, Northern Norway. Unpublished report. Norges geologiske undersøkelse, $28 \mathrm{pp}$.

Pharaoh, T.C. 1984: The Precambrian geology of the northern part of mapsheet Skoganvarre 2034 IV. Unpublished report. Norges geologiske undersøkelse, $14 \mathrm{pp}$.

Roberts, D. \& Davidsen, B. 2011: Bedrock geological map Lakselv 2035 III, 1:50,000, revised preliminary version. Norges geologiske undersøkelse.

Rosenbaum, J.M. \& Sheppard, S.M.F. 1986: An isotopic study of siderites, dolomites and ankerites at high temperatures. Geochimica et Cosmochimica Acta 50, 1147-1159.

Shieh, Y.M. \& Taylor, H.P. 1969: Oxygen and carbon isotope studies of contact metamorphism of carbonate rocks. Journal of Petrology 10, 307-331.

Siedlecka, A. 1985: Geology of the Iešjav囚ri冈-Skoganvarre area, northern Finnmarksvidda, north Norway. Norges geologiske undersøkelse Bulletin 403, 103-112. 
Siedlecka, A. \& Roberts, D. 1996: Finnmark Fylke. Bedrock geological map, 1:500,000. Norges geologiske undersøkelse.

Siedlecka, A., Krill, A.G., Often, M., Sandstad, J.S., Solli, A., Iversen, E. \& Lieungh, B. 1985: Lithostratigraphy and correlation of the Archaean and Early Proterozoic rocks of Finnmarksvidda and the Sørvaranger district. Norges geologiske undersøkelse Bulletin 403, 7-36.

Siedlecka, A., Davidsen, B., Rice, A.H.N. \& Townsend, C. 2011: Bedrock geological map Skoganvarri 2034 IV, 1:50,000, revised preliminary version. Norges geologiske undersøkelse.

Surdam, R.C. \& Boles, J.R. 1979: Diagenesis of volcanic sandstones. In Scholle, P.A. \& Schluger. P.R. (eds.): Aspects of diagenesis. Society of Economoic Paleontologists and Mineralogists Special Publication 26, 221-242.

Tuisku, P. 1985: The origin of scapolite in the Central Lapland schist area, northern Finland: preliminary results. Geological Survey of Finland Bulletin 331, 159-173.

Vanhanen, E. 2001: Geology, mineralogy and geochemistry of the Fe$\mathrm{Co}-\mathrm{Au}-(\mathrm{U})$ deposits in the Paleoproterozoic Kuusamo Schist Belt, northeastern Finland. Geological Survey of Finland Bulletin 399, $287 \mathrm{pp}$.

Veizer, J. 1983: Chemical diagenesis of carbonates: theory and application of the trace element technique. In Arthur, M.A., Anderson, T.F., Kaplan, I.R., Veizer, J., Land, L.S. (eds.): Stable Isotopes in Sedimentary Geology, SEPM Short Course No. 10. Society for Sedimentary Geology, Dallas (Chapter 3), pp. 1-100.

Wennervirta, H. 1969: Karasjokområdets geologi. Norges geologiske undersøkelse 258, 131-184. 